\title{
浮選機の性能について
}

広田元英*

\section{The Basic Studies on \#21 Fahrenwald Flotation Machine}

\section{1. 緒 言}

\section{$1-1$ 目 的}

当日立鉱業所はもとより、現在各浮遊選鉱場において 最も普遍的に使用されているファーレンワルド型浮遊選 鉱機は、過去多くの経験を経て現在の設計がなされ、ま たその優秀性によつて広く使用されているのではあろう が、使用する我々にとつては各部分の果たす効果にはま だ不明の点も多く、経験上得られた知識においてもその 効果程度む明らかでない。また粗選、精選、清掃等現場 操業上の使用目的に応じて改良の余地がまだ残されてい ないとはいえない。

このような理由により当所では21番型ファーレンワル ド型浮選機と同様な単一区浮選機を製作し、以前より試 験を行つてきた。

本試験は現在日鉱本社飯島係長が当所在勤中鉱業協会 にて発表したものに、その後試験を続行し追加したもの である。勿論すべての試験が完了したわけではなく、今 後あ引続いて行う予定であるが、現在までの結果に就い て以下に報告する。

\section{1-2 試験浮選機}

試験に使用したファーレンワルド型浮選機のセルは 6 $m / m$ 鉄板製であり、第 1 - 1 図に示すごとくその上面は 21 番型に準じ $960 m / m$ 角とし、高さは $1380 m / m$ である。その側 面の一部に透明セルロイドの空を設け、内部観察を便な らしめた。また槽底には厚さの異なる木板数枚を捰入可 能ならしめ、インペラと槽底との間隔を変化させた。駆 動電動機は15Pのものを使用し、とのVプーリおよび浮 選機のプーリを交換して、インペラの回転数を変化させ た。

基礎試験に当つてはとくに断わら奴限り第 1 表の条件 を標準条件として行つた。

消費電力はワットメータによる直読值を採用し、3 回 の平均を求めた。な纬用電源は $50 \sim 440 \mathrm{~V}$ である。

\footnotetext{
受理 昭和 37 年 1 月 12 日

* 日本鉱業株式会社 日立鉱業所鉱山部選鉱課主任

** ソ連の交献1 ${ }^{2}$ ) UBETHBLE METARRBL 33[8] 16 31 ('60)で はこの逆数、寸なわち発生気泡量当りの動力で表示している。
}

\section{Motohide HIROTA}

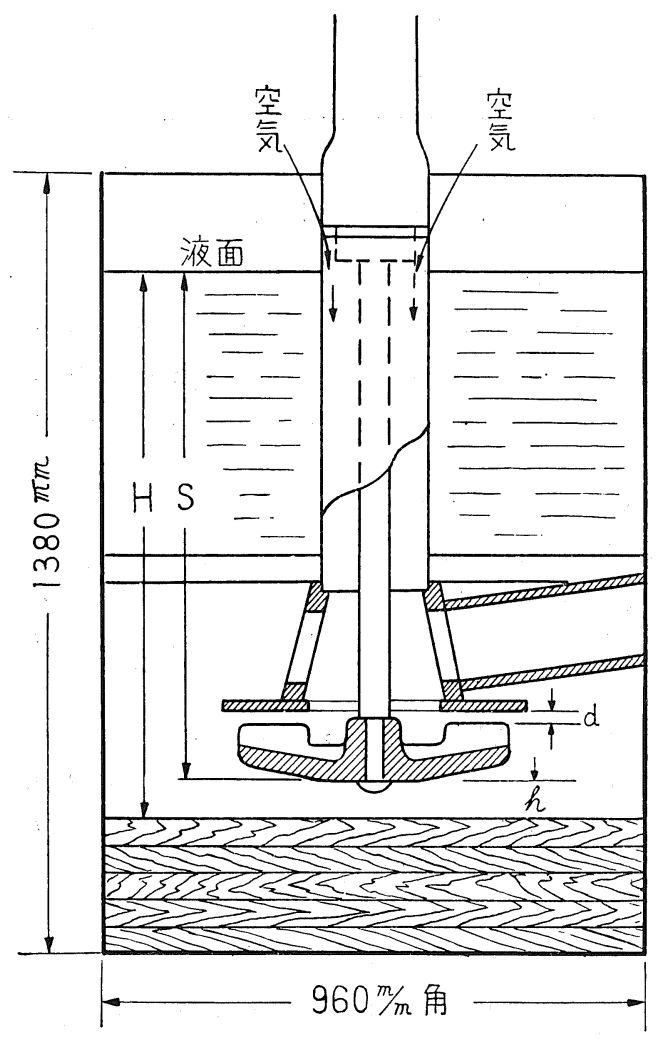

第 1-1 図 試験用単一区浮選機略図

空気量測定は $1 l$ のメスシリンダに水またはパルプを 満たし、これが気泡と置換するに要する時間より算出す る方法によつた。測定は表面10点で行ないこの平均值を あつて空気量 “Q”とした。

\section{1-3 性能の表示}

浮選機の性能を何で表現するかは種々論があると思う が、今回は機械的な面を主とした試験であるので、動力 をワット、空気量を $\mathrm{m}^{3} / \mathrm{m}^{2} \mathrm{~min}$ で表わしてれを基とし てKW 当りの空気量すなわち

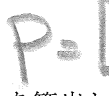

$$
\frac{\mathrm{Q}}{\mathrm{W} \cdot 1000} \cdots \cdots \cdots \cdot \mathrm{m}^{3} / \mathrm{m}^{2} \operatorname{min~} \mathrm{KW}
$$

を算出し、動力指数としてPで表示した。**)

な怙各グラフは第 2・4・1図、第 $3 ・ 3 ・ 2$ 図の動 力を除きすべて同一スケールで描いてある。 


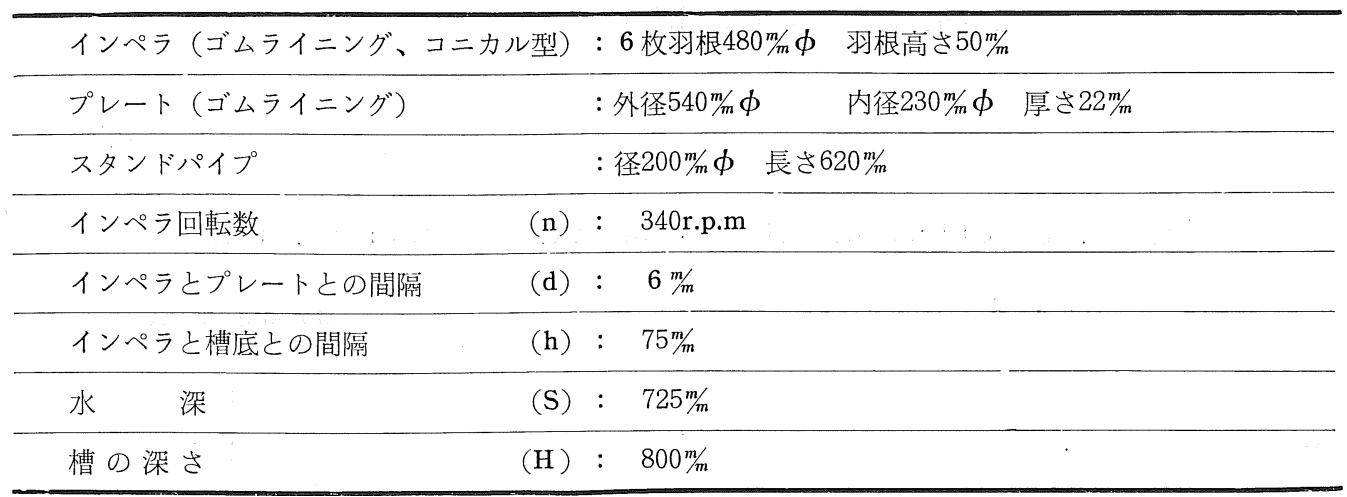

\section{2 標準インペラによる試験}

\section{2-1 水 深 $(\mathrm{S})$}

浮選機の使い方として Deep Cell と Shallow Cell と があるととはよく知られているが、この場合水深が変る ととによつて、動力、空気量がどのように変化するかを 見た。

試験隹当つては $\mathrm{S}$ を変化させ $\mathrm{h}$ は一定とした。したが つて第 1-1図に見るごとくHも自動的に増加する。 試験 media は清水、清水にヤーマFパイン油を 10 $\mathrm{mg} / l$ 添加したあの、および $25 \% \mathrm{pd}$. のパルプの 3 種類 である。

この結果を第 2・1・1図に示す。

動力はいずれの場合にす S の増加に伴い一次函数的に 上昇し、その絶対值は清水が一番低く、起泡剂を添加し た清水、パルプの順に高くなる。

グラフより実験式を求むれば、

$\mathrm{W}=3.43 \mathrm{~S}+1410 \cdots \cdots$ パルプ

$\mathrm{W}=3.12 \mathrm{~S}+1280 \cdots \cdots$.超泡剂添加した清水

$$
\mathrm{W}=3.28 \mathrm{~S}+870 \cdots \cdots \text { 清水 }
$$

となる。

定数項はその media.によつて変るが、S の係数はい ずれあ3.1〜3.5であり似かよつた值を示している。

空気量は当然のととではあるが、Sが増加するにつれ て減少する。これを逆にいえばSを小さくするととによ り空気量を効果的に増加させるととが出来る。

絶対值では清水の場合が一番高く、他の二者は同じ位 であるが傾向はいずれも似ている。

ての結果 $\mathrm{P}$ は S 増加につれて激減する。

\section{2-2 インペラと底槽との間隔}

インペラ々槽底との間隔は狭すぎれば液面が動摇し、 また大きすぎれば dead の部分を生じて沈澱を起すなど のトラブルが発生する。従つてどてか最適点がある筈 であるが、沈澱の生成はパルプを連続給鉱した試験を行 なはなければ判らないので、本試験では動力、空気量に $\mathrm{h}$ がごのように作用するかを調べた。

試験に当つては $\mathrm{h}$ を変化させ $\mathrm{S}$ を定としたので $\mathrm{H}$ б 变化している。 $(\because \mathrm{H}=\mathrm{S}+\mathrm{h})$
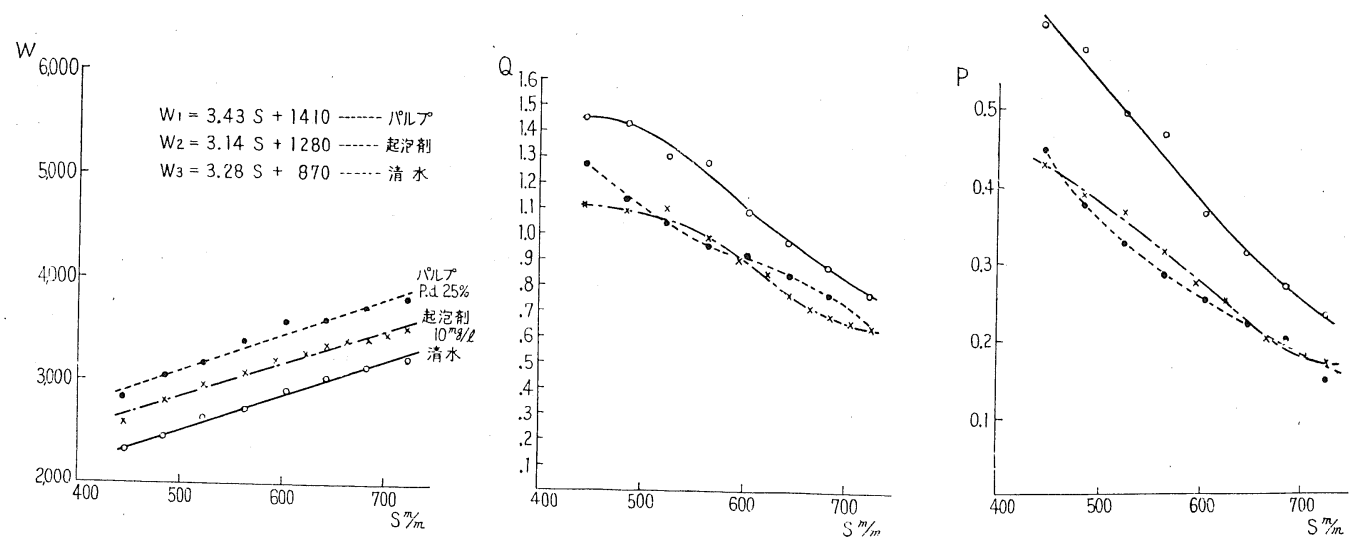

第 2・1・1図水 深 $(\mathrm{S} \mathrm{mm})$ 
試験 media は清水と $25 \%$ p.d のパルプとである。

\section{この結果を第 2・2・1 図に示す。}

動力は一般にパルプの方が高いととは予想されたが、 いずれの場合にあ初めdが増加するに従つて急激に減少 する。乙れは槽底とインペラ底部との間の抵抗が小さく なるためと考えられる。乙の值は $\mathrm{h}=60 \sim 80 \mathrm{~m} / \mathrm{m}$ で極小と なり、h が更に大きくなれば再び大きくなるが、この増 加率は比較的ゆるやかである。乙れは第 2・2・2図に 示すごとくインペラ下部にある Water Column を廻転 させるためと考えられる。この影響はあまり深部までは 及ばないので、 $\mathrm{h}$ が120〜 150 m/m以上になると平衡状態と なる。

空気量についてはほとんご顕著な差は見られなかつ た。

$\mathrm{P}$ は初め増加し、次で $\mathrm{h}$ が $120 \mathrm{~m} / \mathrm{m}$ 附近より平衡状態と なる。

したがつて当試験機では $\mathrm{h}=60 \sim 80 \mathrm{~m} / \mathrm{m}$ で行うのがよ ()。

\section{2-3 インペラとプレートとの間隔}

インペラとプレートとの間隔すなわち gap は当所では 6 m $/ m$ を標準としてセットしているが、これが適当な值で あるかも不詳であるので効果を試験した。

試験に当つてはHを一定とした。こうすればプレート の位置はウイングで固定されているので、 $\mathrm{d}$ の変化とと あにSあ変化している。

·試験 media は清水と $25 \%$ p.d のパルプとである。

この結果を第 2・3・1 図に示す。

動力は水、パルプ何れの場合にも初めd を増加させ てもほとんど一定であるが、d が $20 \% / m$ を超えると増加を 始め、更に $40 \frac{m}{m}$ を超えると急激に上昇する。乙れは第 2

・3・2図に示すごとくインペラがプレートと離れるこ とによりインペラ上部の Water Column 在逻すように なるためと考えられる。 これに対し空気量はdの増加に伴い極めてゆるやかに 増加する。

Pはdの増加に従い減少している。

したがつて当試験機では $\mathrm{d} は 6 \sim 20 \mathrm{~m} / \mathrm{m}$ の範囲内ならい ずれでもよい。あまり小さい值では空気量が不安定とな る。これは Cavitation のためと思われる。

\section{2-4 インペラの回転数}

インペラの回転数が動力や空気量に大きな影響を与え るであろう事は想像に難くない。そこで $\mathrm{n}$ を 216〜351 r.p.m の間で10段階に変化させその効果を見た。

試験 media は清水である。との結果を第 2・4・1 図に示す。
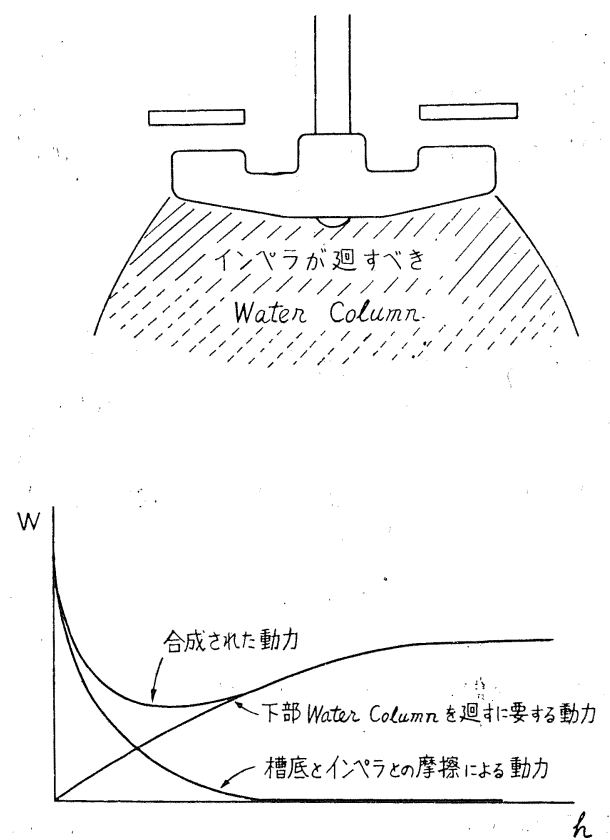

第 2・2・2図 インペラ下部の Water Column. および h の変化と動力変化の関係

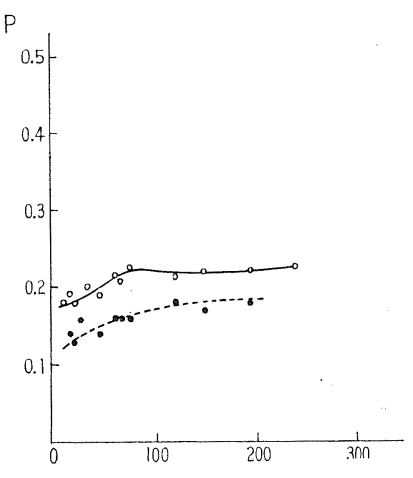

第 2・2・1図 インペラを槽底との間隔 $(h \mathrm{~mm})$ 

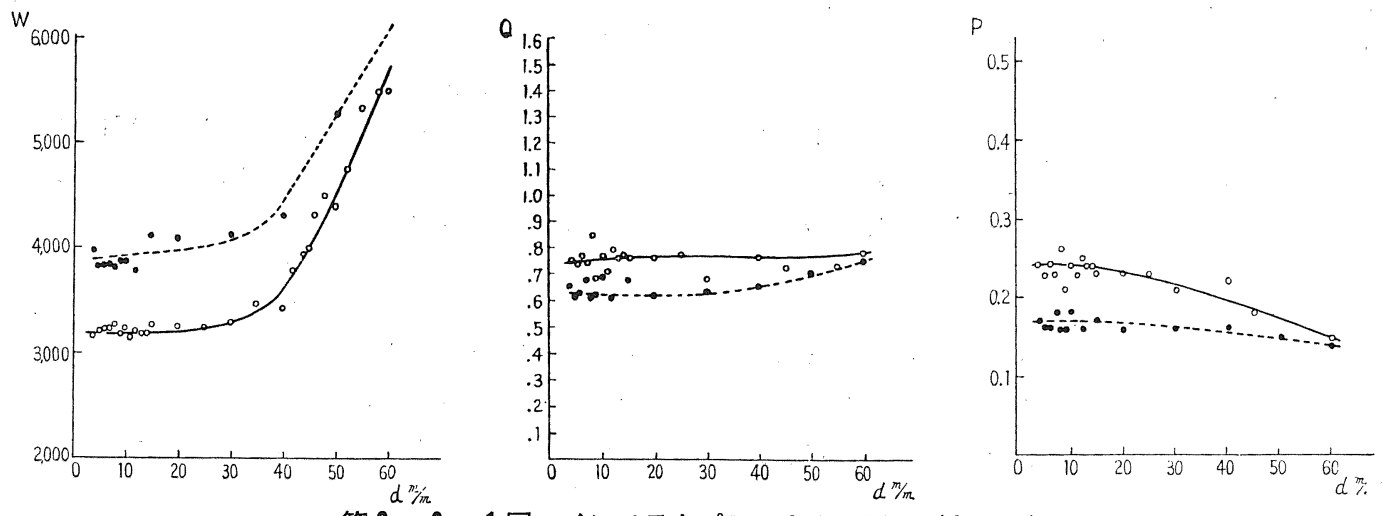

第 2・3・1図 インペラとプレートとの間隔 $(\mathrm{d} \mathbf{~ m m})$

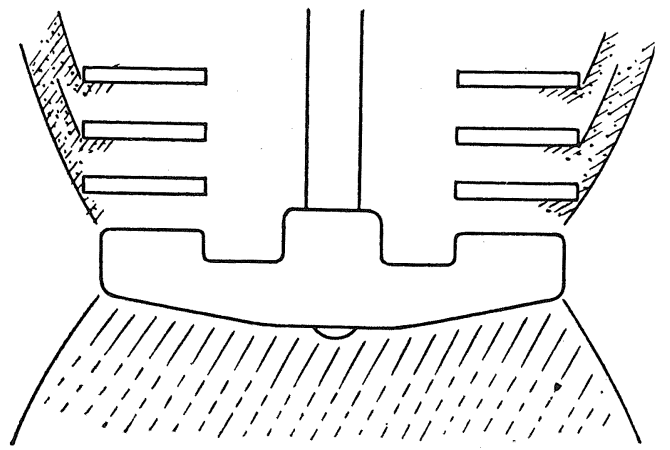

第 2・3・2図 d の増加とともに増加する上部 Water Column.

動力は $\mathrm{n}$ が大になるに従い急激に増加し、またその増 加率も遂次増加して行くことが見られた。との曲線を $\mathrm{W}=\mathrm{an}^{\mathrm{b}}$ と見做し、実験式を求めれば、

$$
\mathrm{W}=0.0431 / \mathrm{n}^{\mathbf{1} \cdot 92}
$$

となる。

空気量むnが大になるにつれて初めは急激に増加する が、400〜450r.p.m の間に変曲点を生じそれ以上は空気 量は増加するも増加率は漸減している。
Pは 420〜440r.p.m 程度で極大值となり、動力当りの 空気量はこの附近が最も多いことを示している。

\section{2-5 パルプ比重}

從来までの試験で清水よりも常にパルプの方が動力は 高く空気量は少なかつた。乙れは予想されたととであつ たが、とれがどの程度であるかは不明であるので標準状 態に打ける試験を行つた。

試験は濃度 0 ～44.2\% p.d 間を11段階に分けて行つ た。これをパルプ比重に換算すれば1.00〜1.40となる。

\begin{tabular}{|l|l|l|l|l|l|l|l|l|l|l|l|}
\hline p.d & 0 & 5.7 & 8.7 & 14.8 & 19.4 & 22.6 & 28.7 & 32.0 & 38.0 & 41.5 & 43.5 \\
\hline$\rho$ & 1.10 & 1.04 & 1.06 & 1.11 & 1.15 & 1.17 & 1.23 & 1.27 & 1.33 & 1.38 & 1.40 \\
\hline
\end{tabular}

この結果を第 2・5・1図に示す。

動力は $\rho=1.1$ 位まではほとんど変りない。これは濃度 の影響よりも Idoling Power の方が大であつたためと 思われる。1.1を超すと増加を初める。しかしての值は $\rho=1.40$ で清水の $120 \%$ 程度であり予期したより低かつ た。A.M.White \& E.Brennel $\left.{ }^{3}\right)$ によれば $\rho^{0.86}$ に比例 すると云われているので実験式を求めれば $\mathrm{W}=2726 \rho^{0.956}$ となる。
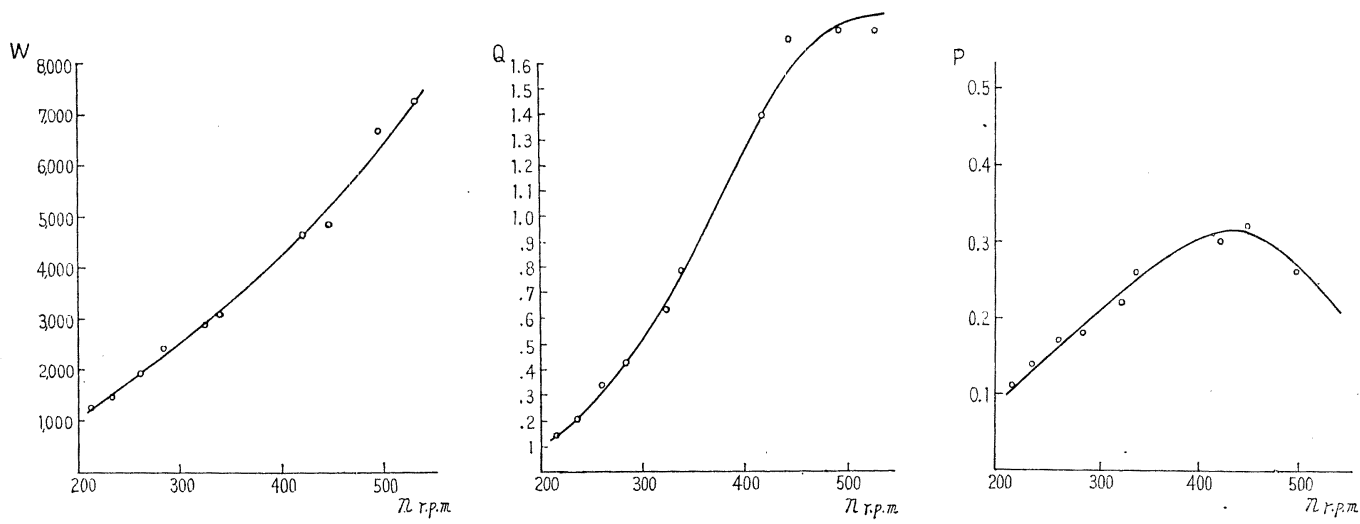

第 2・4.1図 回 転 数 (n r.p.m) 

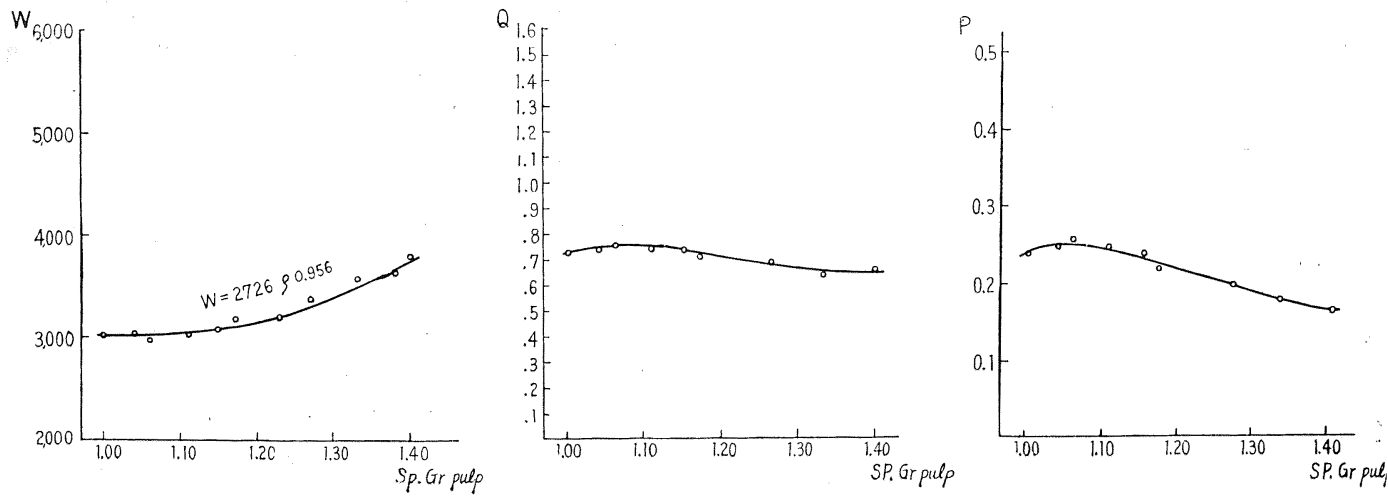

第 2・5・1図パルプ比重

たぶし前述のごとくこの式は $\rho=1.1$ 以下では満足し た。 ない。

空気量も漸減するがその值は $\rho=1.40$ で清水の $84 \%$ 位 でこれも予期したよりも影響む少なかつた。

$\mathrm{P}$ は $\rho$ が大となるにつれて減少し $\rho=1.40$ で清水の68 $\%$ 程度となる。

\section{2-6 プレートの外径}

現場操業中浮選機に装着してあるプレートが摩耗を起 せば動力が上昇し、空気量も増加する傾向があることが 観察された。そこで試験機に摩耗したプレートを装着し てデータをとつた結果第 2 表に示すごとく摩耗の度合が 進むに従い動力、空気量とも上昇することが確認され

この様にプレートが予期以上に重要な作用を及ぼす様 であるので中空部径は一定とし、外径の異つたプレート を10個鉄板にて作成し試験を行つた。

この場合インペラは標準のものを使用し、試験 media は清水である。

この結果を第 2・6・1 図に示す。

動力はプレート径が大な方ではほぶ一定であるが、約 $\mathrm{D}=520 \mathrm{~m} / \mathrm{m} \phi$ 以下では急激に増加する。これは第 2・6

・2図に示すごとくプレート径が小さくなることにより インペラ上部の Water Column を趈すためであろう。 なおプレートなしの場合、動力は $12,990 \mathrm{w}$ であつた。

第 2 表 プレート摩耗の 影響

\begin{tabular}{|c|c|c|c|c|}
\hline プレート重量 $(\mathrm{kg})$ & 動 & 力(ワット) & 空 $\begin{array}{c}\text { 気 } \\
\left(\mathrm{m}^{3} / \mathrm{m}^{2} \text { min }\right)\end{array}$ & 備 \\
\hline 20.90 & & 3,300 & 0.70 & 品 \\
\hline 18.50 & & 3,380 & 0.74 & $\begin{array}{l}\text { 表面のゴムライニングは摩耗しているが、 } \\
\text { 稟はほんど摩耗していない。 }\end{array}$ \\
\hline 16.00 & & 3,840 & 0.73 & $\begin{array}{l}\text { 表面のライニングはほとんどはがれているが } \\
\text { 自はほとんどはがれていない。 }\end{array}$ \\
\hline 4.80 & & 4,640 & 0.90 & $\begin{array}{l}\text { 表面、裏面ともほとんどライニングははがれ } \\
\text { ている。 }\end{array}$ \\
\hline
\end{tabular}
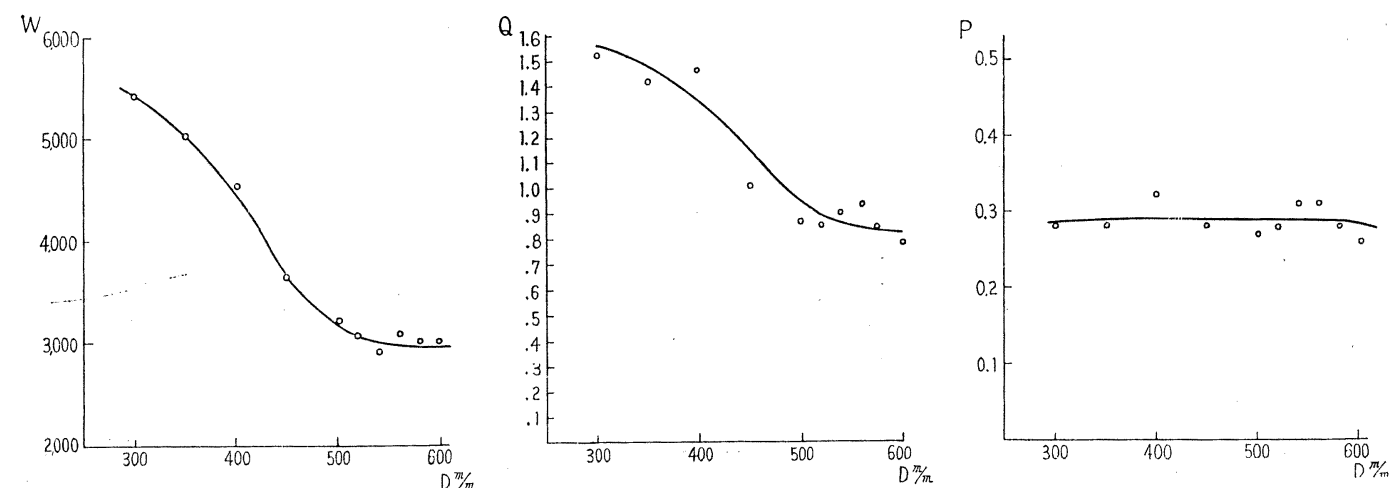

第 2・6・1図 プレートの外径 $(\mathbf{D} \mathrm{mm})$ 


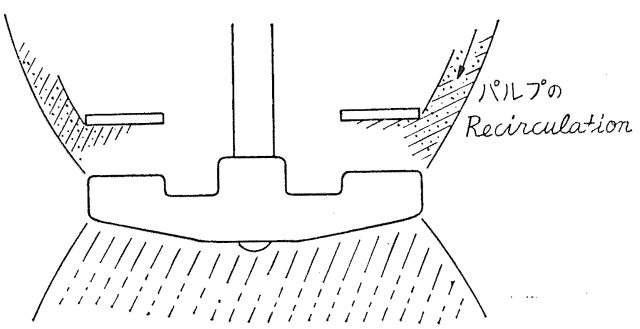

第 2・b・2図 d の減少とと屯に増加する上部 Water Column とパルプの Recirculation

空気量も動力と同様な傾向であつた。とれはプレート 径が少になるとパルプの Recirculation が良くなるので

Suction が強くなるためと考えられる。Recirculation を多くすれば空気量が増すととは操業用の Denver 浮選 機においてあ見られる現象である。しかしプレートなし の場合は空気量少なく $0.64 \mathrm{~m}^{3} / \mathrm{m}^{2} \cdot \min$ であつた。

Pはばらついてはいるがほぶ一定值と見られる。

\section{2-1 インペラ羽根高さ}

インペラの羽根高さを増せば攪拌は强力となり、沈澱 を防止すると同時に空気量を増加するととが知られてい るが、動力の増加も避けられない。当所では以前 $25 \frac{m}{m}$ で あつたのを上記の理由から現在では $50 \mathrm{~m} / \mathrm{m}$ とている。

この効果を験するため鉄製コニカルインペラを作成 し、これに羽根をネジ止めして試験を行つた。したがつて インペラの重量は羽根高さととあに増加するので、これ
が Idolng Power を増加させることが理論上考えられる が0 $\frac{m}{m}$ で $41.7 \mathrm{~kg} 、 60 \frac{m}{m}$ で $47.7 \mathrm{~kg}$ であつたのでその影響は 少ないと思わ机る。乙の結果を第 2・1・1図に示す。

動力は羽根高さが増加するにつれて予想通り急激に増 加する。

空気量む増加するが $30 \%$ 位から増加率は下りゆるやか となる。

$\mathrm{P}$ は30m/m近くで極大となり、それ以下は下るが、この 減少率は $30 \frac{m}{m}$ 前の増加率より小さい。

したがつて効率は $30 \mathrm{~m} / \mathrm{m}$ が最高ではあるが、それ以上で あそれ程低くはなく、沈溉を防ぐなどの必要があれば増 加させるべきである。

\section{3 その他の型式のインペラによる試験}

前述のごと〈当所におけるインペラはコニカルディス ク型を標準としているが、インペラの型状はこの他にも 数多くある。その主なあのはマルチブレード型とレシー デット型であるので、この二種を鉄板で設計製作し試験 を行つた。(写真1〜8参照)

しかし鉄板製であるために重く、“このデータを軽いゴ ム゙ライニングしたコニカルディスク型と比較するととは 無理と思わ杖ので、コニカルディスク型のインペラ及 びプレ゙ートをも鉄板で製作し比較した。その重量を第 3 表に示す。

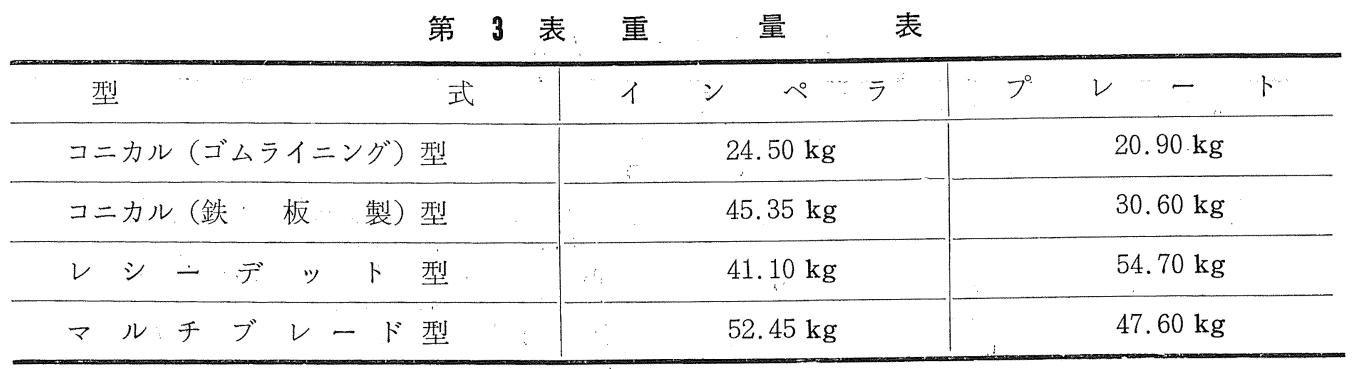
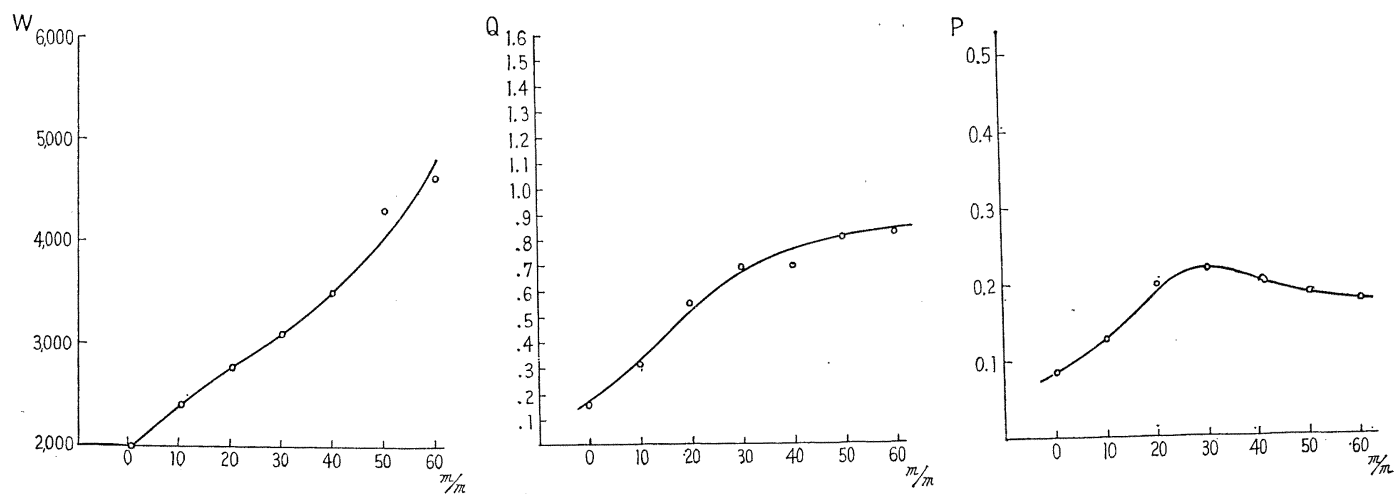

第 2・1・1図 インペラ羽根高さ $(\mathbf{m m})$ 


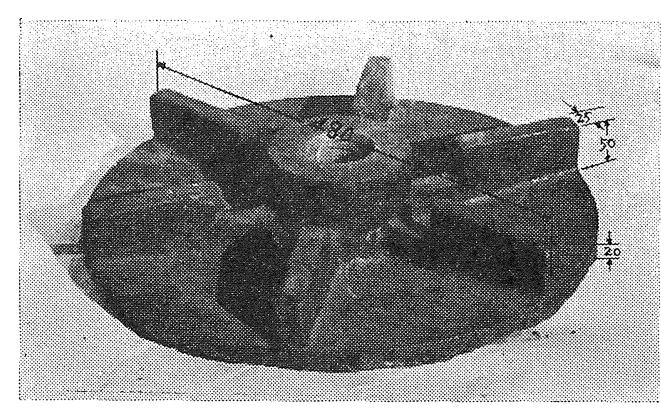

Photo 1 鉄製コニカル型インペラ

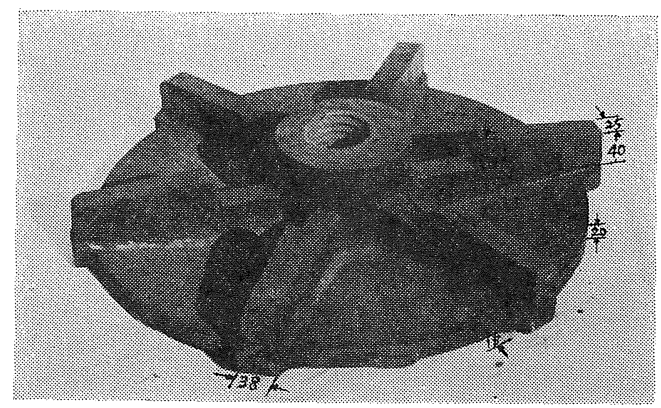

Photo 3 レシーデット型インペラ

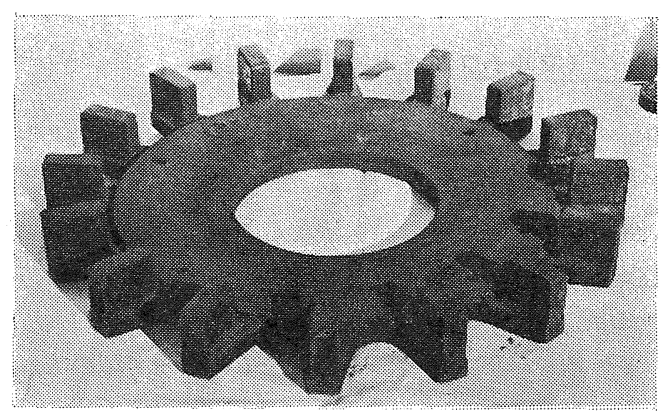

Photo 5 レシーデット型用プレート(裏面)

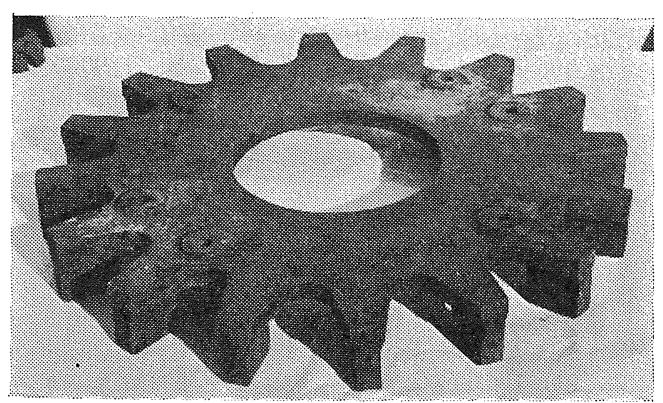

Photo 7 マルチブレード型用プレート(表面)

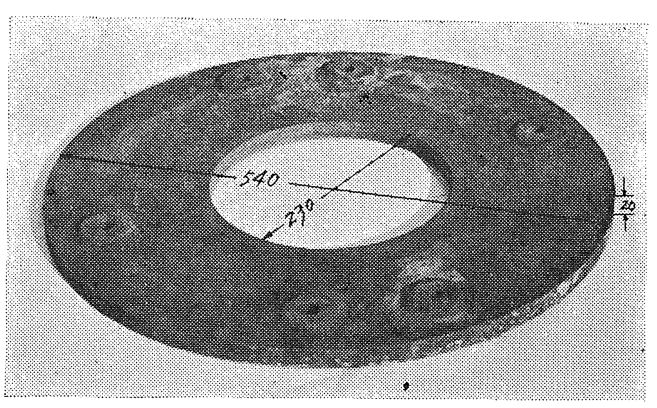

Photo 2 鉄製コニカル型用プレート

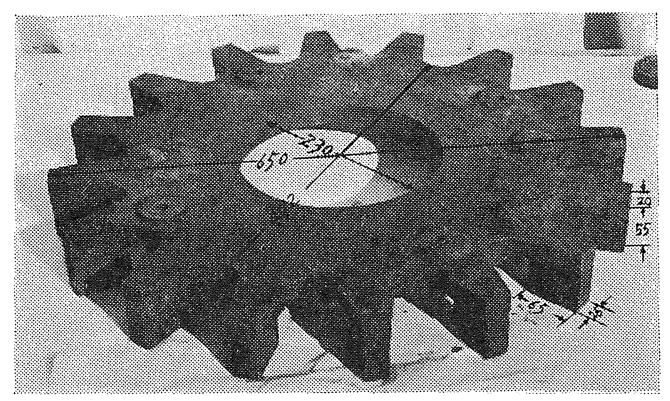

Photo 4 レシーデット型用プレート(表面)

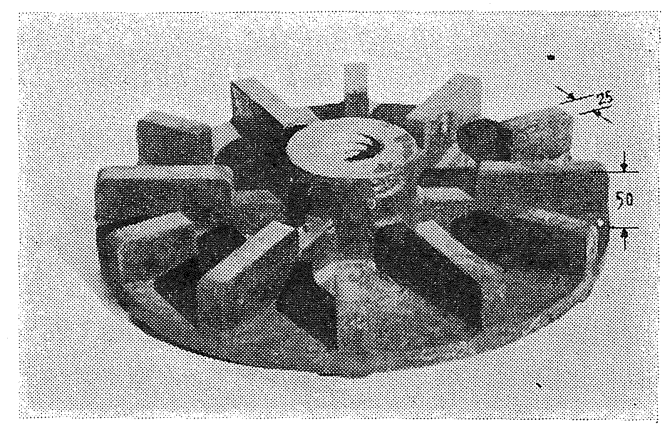

Photo 6 マルチブレード型インペラ

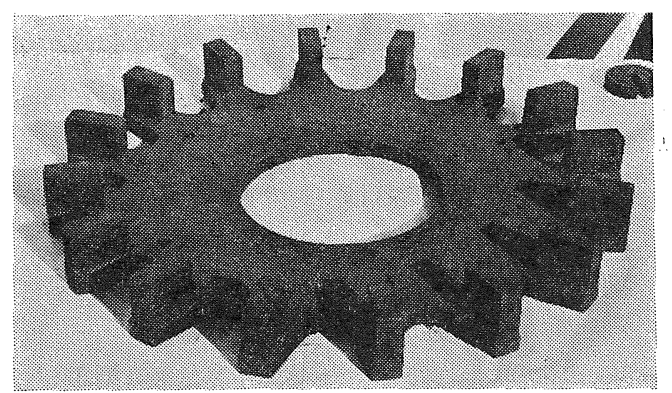

Photo 8 マルチブレード型用プレート(裏面) 

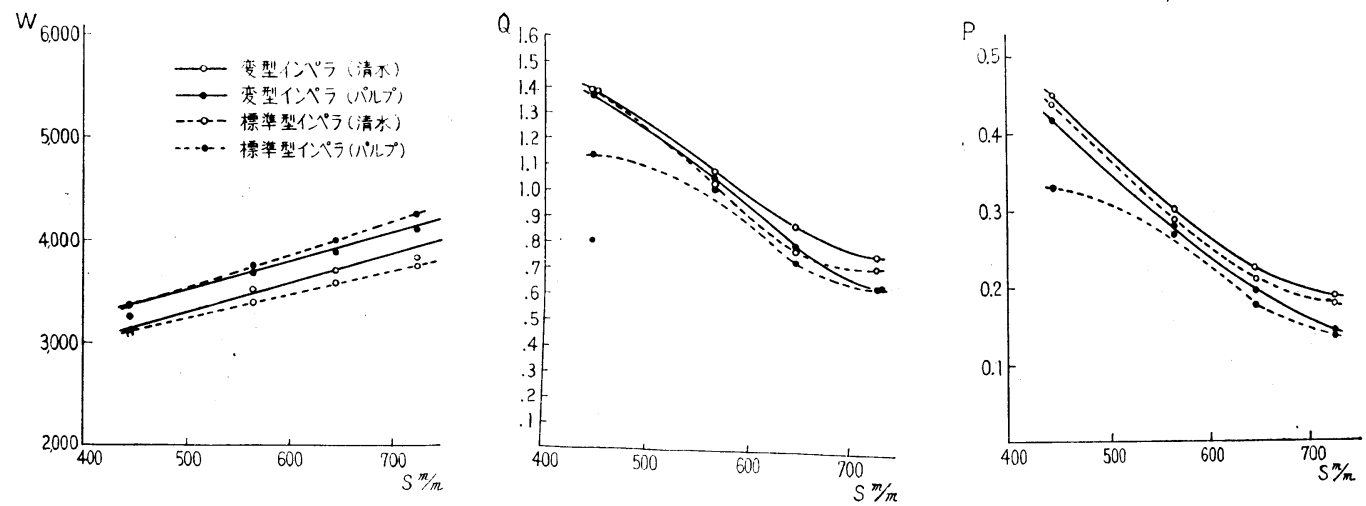

第 3・1・1図 水 深 $(\mathbf{S} \mathrm{mm}) \quad($ Iシーデット型）
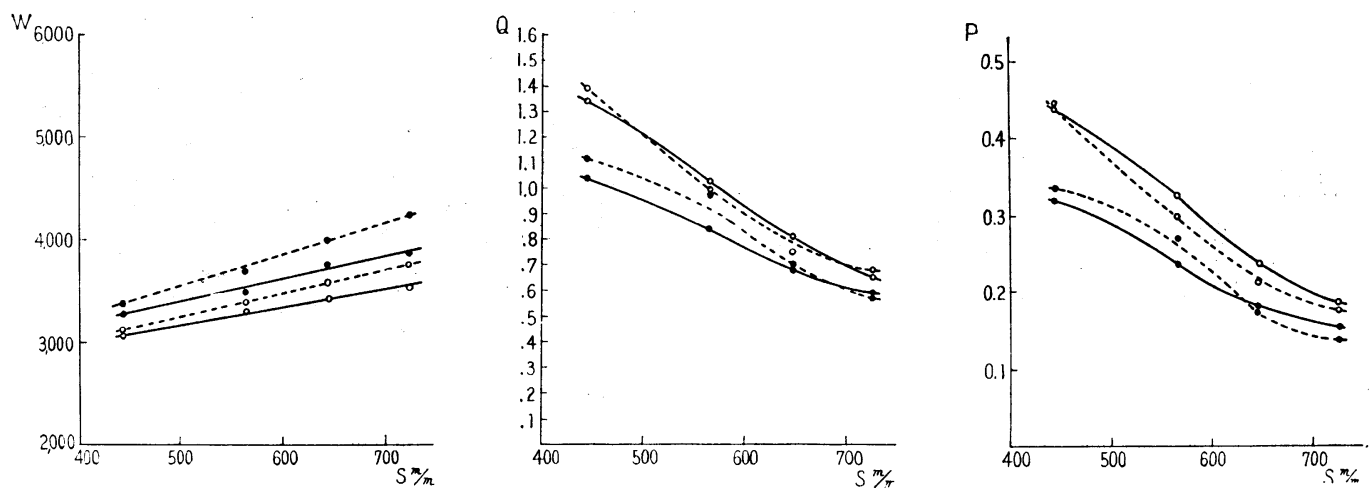

第 3・1・2図 水 深 $(\mathbf{S} \mathrm{mm})$ (マルチブレード型)

試験は水深 $(\mathrm{S})$ インペラと槽底との間隔 $(\mathrm{h})$ 及びイン ペラとプレートとの間隔 (d)について行つた。

試験 media はすべて清水と $25 \%$ p.d のパルプとの二 種である。

また各グラフは変形インペラのデータを実線で表し、 同時に比較のために鉄製コニカルディスク型インペラの データを破線で示した。

3 - 1 水 深

$3 \cdot 1 \cdot 1$ レシーデット型インペラ（第 3・1・1

図)

動力は清水およびパルプの何れの場合にも直線的に増 加しておりその係数は “3” 程度である。またての絶対 值もコニカルディスク型とそれ程違わない。

空気量もグラフの形状はコニカルディスク型と大差な いが、絶対值はレシーデット型の方がやや高い。

従つて $\mathrm{P}$ もほとんどコニカルディスク型と大差ないが レシーデット型の方がやや高くなつている。

$3 \cdot 1 \cdot 2$ マルチブレード型インペラ（第 3・1・

2 図)

動力は清水およびパルプの何れの場合にも直線的に増
加しているが、その係数は何れもコニカルディスク型よ りあ小さく“2”程度である。

空気量は傾向も絶対值もほとんどコニカルディスク型 と変りないが、パルプの場合はマルチブレード型の方が やや少なかつた。

また $\mathrm{P}$ あパルプの場合にはマルチブレード型の方が低 い傾向であつた。

なおデータ数が少ないので実験式は明記出来ないがそ の大体の值は

$$
\begin{aligned}
& \text { コニカルディスク型 清 水 } \mathrm{W} 2.4 \mathrm{~S}+2,000 \\
& \text { コニカルディスク型 パルプ W3.2S }+1,9000 \\
& \text { レシーデット型 清 水 } \mathrm{W}=3.0 \mathrm{~S}+1,800 \\
& \text { レシーデット型 パルプ } \mathrm{W}=2.9 \mathrm{~S}+2,100 \\
& \text { マルチブレード型 清 水 } \mathrm{W}=1.6 \mathrm{~S}+2,400 \\
& \text { マルチブレード型 パルプ } \mathrm{W}=2.1 \mathrm{~S}+2,400
\end{aligned}
$$

である。

\section{3 - 2 インペラと槽底との間隔}

$3 \cdot 2 \cdot 1$ レシーデット型インペラ（第 3・2・1

図)

動力はコニカルディスク型インペラに見られたような 

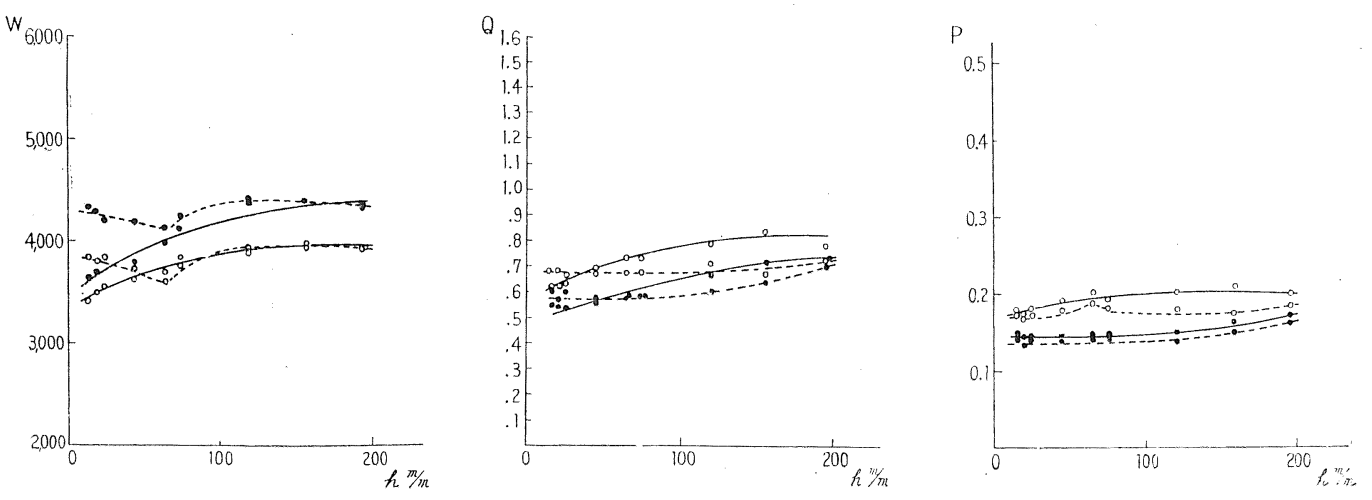

第3・2・1図

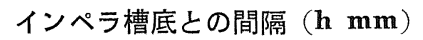

(レシーデッド型)
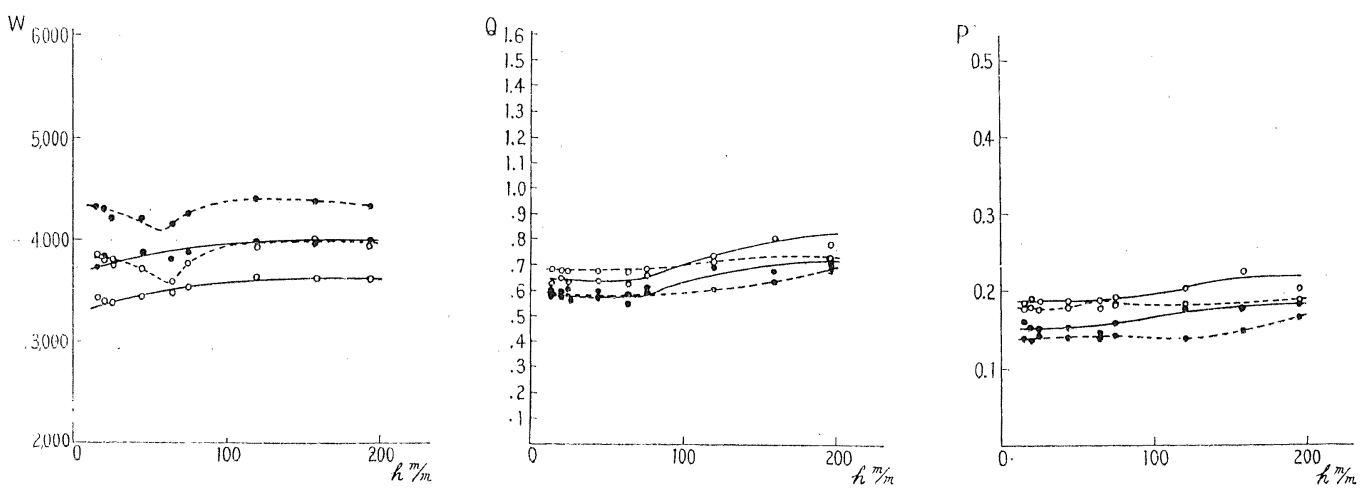

第 3・2・2図 インペラと槽底との間隔（h mm）（マルチブレード型）

$70 m / m$ 前後の極小部分が見られず、 $\mathrm{h}$ の増加に伴つて初め はやや急激に、100 m/m 超すとゆるやか化增加し、120 m ～150 m m 以上では平衡佰する。

これはインペラ下部の Water Column を廻わすため に消費される動力に刘し槽底とインペラとの間の抵抗等 の他の因子が比較的小さかつたと考元られるが、この理 由についてははつきりと断定はできない。

動力の絶対值は初めレシーデット型の方が低いが、平 衡に達すれればほメ゙コニカルディスク型と同等となる。

空気量はコニカルディスク型ではほば一定であるのに 対し、レシーデット型のそ机は動力量之同様な傾向を示 し、約 $50 m \frac{m}{m}$ 以上では絶刘值はコニカルディスク型を上廻 つている。

$\mathrm{P}$ はほぶ似かよつた図形であるが一般にレシーデット 型の方が大きい。

$$
3 \cdot 2 \cdot 2 \text { マルチブレード型インペラ（第 3・2・ }
$$

2図)

動力はレシーデット型と同様の図形であるが、その絶 対値は 3 種のインペラの中で最小である。

動力增加の傾向に対してはレシーデット型の之き之同 様にはつきり1,た理由は述べられないが、コニカルディ
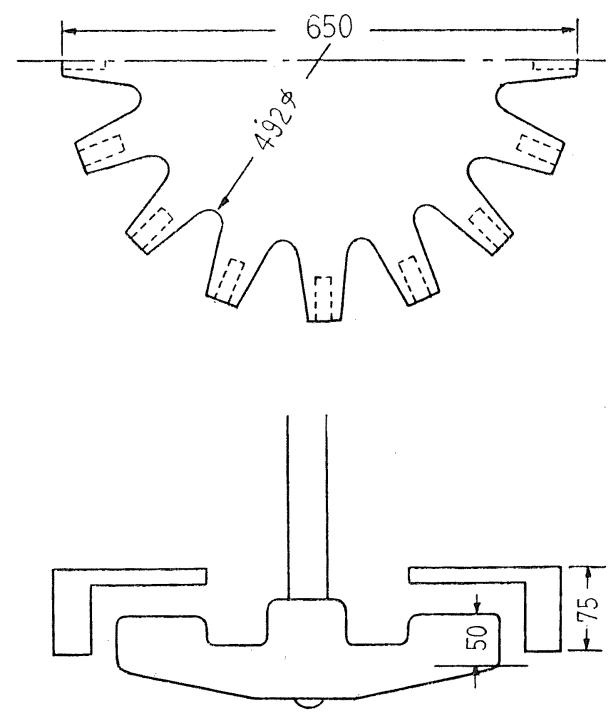

第3・2・3図 マルチブレード型インペラおよび プレート略図

スク型のプレートが単純な円板型であるのに対し、变形 インプラ用のプレートは第3・2・3図に示すごとく何 れも切込みおよび邪魔板のついたあのであるので、プレ 


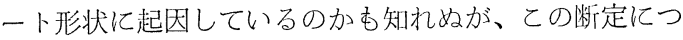
いては今後の試験にまたね壮ならない。

空気量 $\mathrm{P}$ は何れ屯動力が増加している間はほぼ一定で あり、動力が平衡に達する $70 \mathrm{~m} / \mathrm{m}$ 前後からやや増加してい 万。

3 -3 インペラとプレートとの間隔

$3 \cdot 3 \cdot 1$ レシーデット型インペラ（第 3・3・1

図)

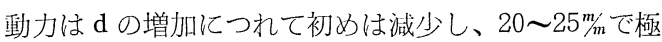
小值を示し、次いて再び増加する。

この理由は前述のごとくプレートに16枚の邪魔板があ るので、これとインペラ羽根間に摩擦抵抗を生ずるが、 d の増加に共に第 3・3・3 図に示すごとくラップして

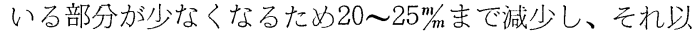
上になれば 2 ・3 で述べたでとく、上部の Water Column を廻すためと考えられる。

動力の絶刘值はコニカルディスク型と同等かやや小さ w。

空気量は何れむ動力之似た傾问を示している。したが つて条件によつてコニカルデイスク型より大きくも小さ くもなる。

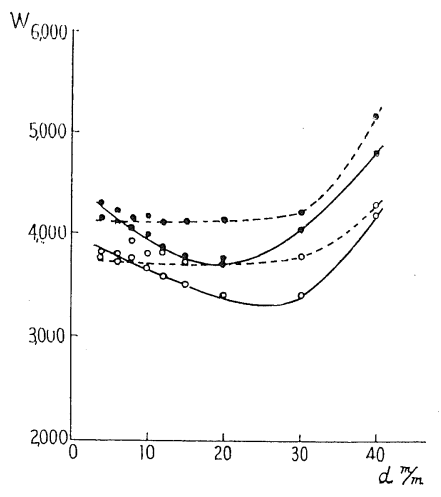

第 3.3.1这

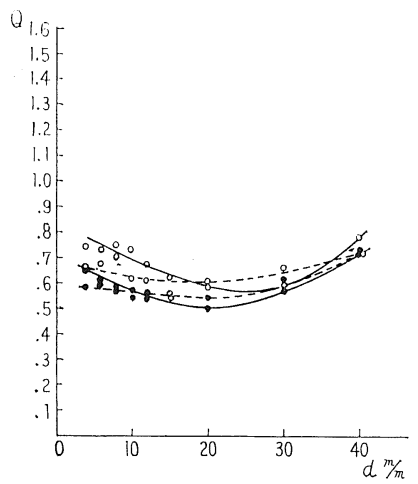

(d mm) (レシーデット型)
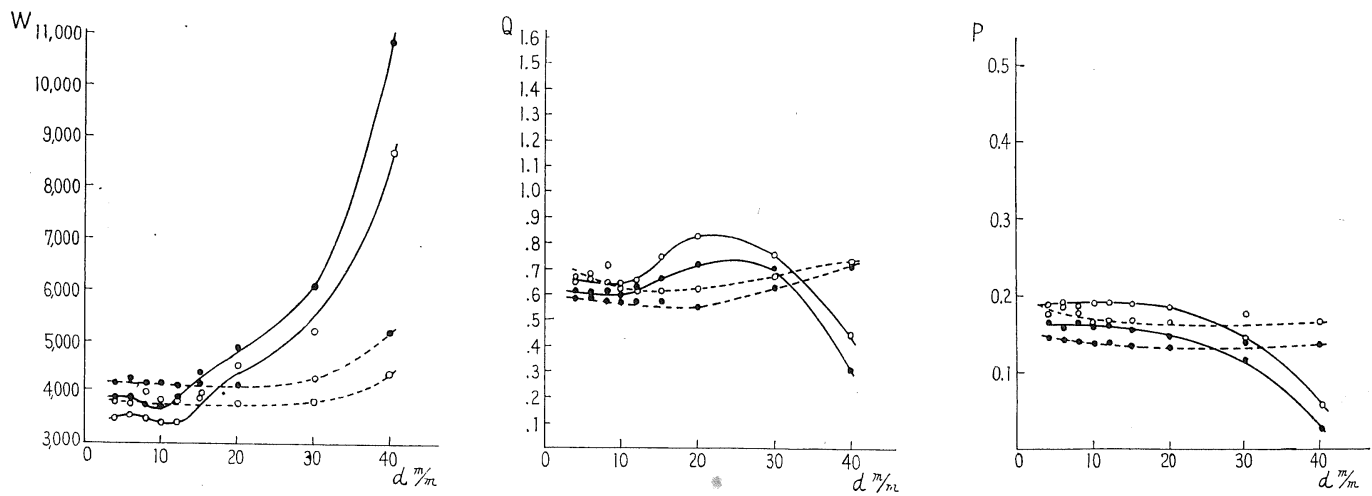

第 $3 \cdot 3 \cdot 2$ 図 インプラとプレートとの間隔 $(\mathrm{d} \mathbf{~ m m})$ (マルチブレード型)

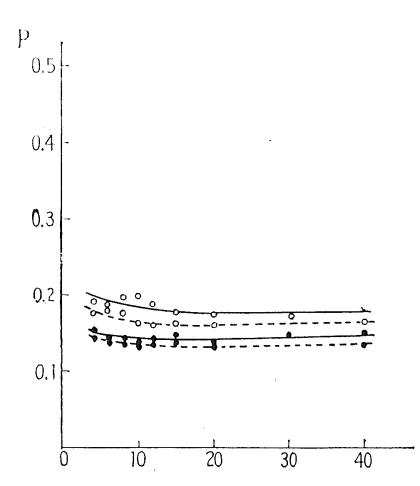

・ 3 ・ 2 マルチブレード型インペラ（第 3・3・ 2 図)

動力は $\mathrm{d}=10 \mathrm{~m} / \mathrm{m}$ 位で極小值のごとくなり、その後は
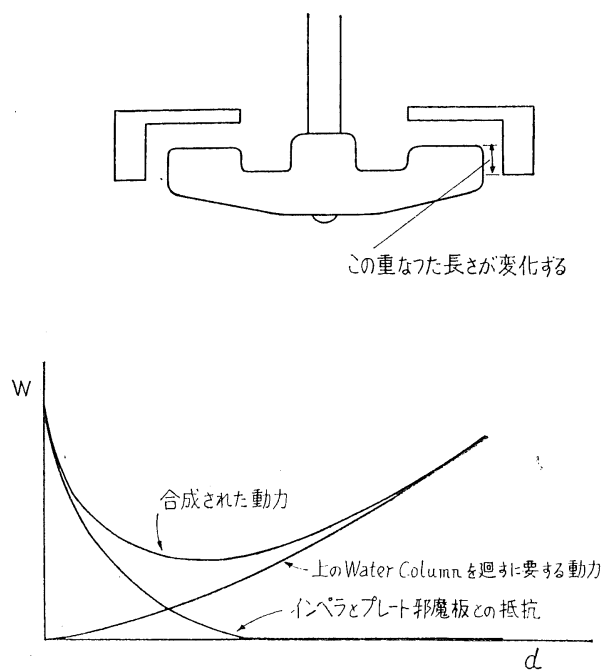

第 3・3・3図 レシーデッド型およびマルチブレ ード型インペラの d の変化と動力変化との関係

(レシーデット型) 
$\mathrm{d}$ の増加之共に急激に增加し、 $30 \mathrm{~m} / \mathrm{m}$ を超えると一層甚だ しく上昇する。これは羽根数が多いため上部 Water Column の影響を受け易く、30m以上では Cavitation に 打ち克つためのみに、動力がいたづらに消費されている と考えられる。したがつて空気量も $\mathrm{d}=10 \mathrm{~m} / \mathrm{m}$ 位より增加 を始めるが、20〜 $25 \frac{m}{m}$ で極大值となり、それ以降は極端 に低下する。またこの時には細かい気泡の他に大きい気 泡が多量に生じ Boiling のごとき様子となつた。

$\mathrm{P}$ は $\mathrm{d}=20 \mathrm{~m} / \mathrm{m}$ 以上よりすでに下り出し、30 $\frac{m / m}{m}$ 超える と急激汇隇少する。

このととからコニカルディスク型、レシーデット型に 扔いても d を極端に大きくすれば、プレートが装着され てないと同様な効果となるために、マルチブレード型と 同様な結果を示す事が推定される。

\section{4 総括}

前記各条件において21番型ファーレンワルド単一区試 験機に执いて行つた基礎試験の絬果を総括すれば次ので とくであある。

（1）インペラ底淔から水面までの深さと動力との関係は 一次菡数で表現出来、動力をワット、水深を $\mathrm{mm}$ で表 わした場合の方向係数は、コニカルディスク型インべ ラ、レシーデット型インペラでは “ 3 ” 前後、マルチ ブレード型インペラでは “2”前後である。空気量は $\mathrm{S}$ を減ずるととによつて効果的に増加する。

(2) インペラと槽底との間隔と動力との関係は、コニカ ルディスク型インペラの場合、 $\mathrm{h}=70 m / m$ 前後に極小值 が存在するが、レシーデット型インペラ、マルチプレ 一ド型インペラの場合には見られなかつた。とれはプ レートの形状も影響していると推察されるが、この確 認は今後の試験をまたねばならない。

（3）インペラとプレートとの間隔と動力との関係は、何 机も $\mathrm{d}$ の増加に従い急激に増加する。また牙魔板付プ レートを用いた場合には極小值が現れる。 空気量はd の増加と共に増加して行くが、次第に平 衡状態となりある点を超えると急激に減少する。

（4）回転数の増加により動力は $\mathrm{n}$ の1.9乗に比例して急 激に增加する。

空気量す始めは急激に増加するが、400〜450 r.p.m. で変曲点を生じ増加率は減少する。

$\mathrm{P}$ には極大值が存在する。

(5) パルプの比重の增加により、動力は $\rho$ の0.96乗に比 例して增加する。

空気量は減少するが、動力、空気量とも予想より影 響は少なかつた。
（6）プレートの外径が小にな机、動力、空気量とも增 加する。

（7）インペラ羽根高さが増加すれば、動力は急激に増加 する。

空気量は初めは急激に、30 m m 以上ではゆるやかに增 加する。

P には極大值が存在する。

(8) レシーデット型インペラ、マルチブレード型インペ ラについてはまだ試験項目が少ないので、はつきりし た結論は出し得ないが、おのおの個性的な特性を有し ている。乙れらの特性が現場操業の各系統における諸 要求にどのように刘応するか怯不明であり、またイン ペラのみの特性かプレートの持つ特性かをむまだ不明 である。これに関しては今後も試験を行ないたいと考 えている。

以上不充分なデータ、不明確な説明ではあつたが、各 所でファーレンワルド型浮選機が使用されている現在、 現場操業を行なうに当つて幾分かの参考に役立つことが あ机ば幸甚である。

\section{5 謝 辞}

本報告は緒言であ述べたでとく、本社飯島係長の研究 を骨子として、さらに試験を行なつたものである。試験 を行なうに当つては、伊滕課長をはじめ、当所選鉱課各 位のご指導、ご協力を得た。ここに深甚な謝意を表する 次第である。

\section{文献}

1 ) O.A. ШУMKOB ; 迅速浮選法の実験的応用方法 之将来性 ЦВЕТНЫЕ МЕТАЛЛЫ 1959

2) В.А. РУНДКВИСТ, С.И. МИТРОФАНОВ ; 上記論文に関する討議 ЦВETHЫЕ MЕТАЛЛЫ 1960

3 ) A.M. White \& E. Brennen; Trams Am, Inst Chem, Engin (30) 585 597 1934

4 ) A.F. Taggart; Handbook of Mineral Dressing

5 ) C.W. Thomas; Madification to Flotation Cells at the Zinc Corporation Limited. the Aust I.M. M. No. 1781956

6 ) M. Clement; Verschleisserscheinungen in Flotationszellen. Wear Vol 1 Nr 1 Aug 1957/58 P $58 \sim 63$

7) 林大輔; Fahrenwald 浮選機のインペラにおける気 泡の流れ模様 日本鉱業会誌

8 ) 龟井三郎他; 化学機械 (18) No. 21949 